\title{
Communities Inclusion of Urban Tourism Development: The Case of Bandung City, Indonesia
}

\author{
Yulia Windarti
}

\begin{abstract}
The study seeks insights into the information of the community's activities to reduce adverse impacts on Bandung City tourism development. Local communities of Bandung City are making the effective effort for environmentally friendly tourism. In-depth interview was conducted to 4 (four) communities in Bandung City that recognized by Department of Tourism and Culture, Department of Burial and Landscape, and Department of Environmental Management of Bandung City. The study revealed the challenges of communities' activities to reduce the negative impacts of tourism development which has the positive influence in changing behavior of residents. It is also showed that communities were not familiar with the government's tourism program because they have been not involved in making the program for tourism. The primary information in this study is premised on the opinions of the host communities about tourism development in their localities.
\end{abstract}

Index Terms-Communities, involvement, tourism development, Bandung city.

\section{INTRODUCTION}

The representation of local community's participation in tourism development is a complicated issue that needs to be further investigated. There is ambiguity about the roles of local communities' functions and the link between their views and planning and development outcomes. Previous studies gave little attention to the feelings of local communities about their roles in tourism development, which constitutes a crucial point in the elaboration of a better plan for sustainable tourism in the particular area [1]. The study seeks insights into the information of the role and communities' involvement (perceived role of host communities) in Bandung City tourism. The questions for this study are: how do host communities perceive the growth of tourism in Bandung City? And, what are the roles of community groups in ensuring sustainable benefits from tourism?

Williams and Lawson (2001) define that a community is "a group of people who share common goals or opinions." That community not always a group of people who lives in the same area [2].

Simmons (1994) asserts that it is important to embrace community participation in developing tourism plans and policies for two fundamental reasons. The first is that it is the community that undergoes the transformation, either positive or negative due to Tourism. Second, the city's residents play significant roles in creating the "hospitality atmosphere" that makes tourism flourish or otherwise [3].

Getz (1982) indicated that "indeed" local people were not

Manuscript received July 5, 2016; revised October 11, 2016.

Yulia Windarti is with the Graduate School of International Development, Nagoya University, Japan (e-mail: yuliawindarti@gmail.com). receiving enough benefits. The expansion of the tourist industry in Bandung City has seen many luxurious hotels springing up in the city, while the majority of residents remain in poverty because the proceeds of tourism are not evenly distributed [4]. Matarrita-Cascante at al. (2010) believes that it is important to engage host communities in the process of tourism-related decision-making if the sustainability of the industry is to be achieved. Local communities can play significant roles by identifying and showcasing tourism resources and attractions that could field into the development of tourism. Participation here means active rather just being passive observers at various engagements meetings with other stakeholders [5].

Thus, Pongponrat (2011) asserts that when opportunities for involvement in the project life cycle are extended to host community members, trust and confidence which are essential requirements for sustainability of tourism-related benefit are ensured [6].

Using the case study of local communities in Bandung City, Indonesia, this paper aims to contribute the local communities' inclusion to reduce the negative impacts of tourism development.

Local communities of Bandung City are making active efforts at promoting environmental friendly tourism. Unfortunately, their efforts are not positively rewarded amid inadequate support from the local government as revealed by in-depth interviews conducted with residents of four (4) communities in Bandung City. The interviews further revealed the challenges confronting the Bandung City tourism development and host communities' suggestions to the local government to reduce the negative impacts of tourism. The study also underscored the communities' role and involvement in tourism development. The analyses in this study are premised on the opinions of the host communities about tourism development in their localities.

This paper starts by looking at the profile of case study area and methodology. Detail discussion of the results on local communities' opinion on the impact of tourism promotion, their role to reduce the adverse impacts and suggestion to reduce the negative impacts also covered.

\section{Case Study Area Profile}

Bandung City is located on the main island of Indonesia, the Java Island. Bandung also the capital city of West Java Province. The location is strategic in communication and an economic way where in the West-East connections with the capital, Jakarta, and in the North-South is connecting to plantation area. Bandung is surrounded by mountains, and this demographic position had been influenced the city's temperature [7]. Based on Local Regulation of Regional 
Municipality Level II of Bandung No. 10 of 1989, Bandung area is $16.729,65 \mathrm{Ha}$ [8].

The dynamics of the economy that growing today in Bandung city is the creative economy which includes the creative industries. Government defines the concept as:

"Creative economy focuses on the creation of goods and services by relying on the expertise, talent, and creativity as intellectual property is the hope for the national or regional economy to raise, compete, and achieve excellence in the global economy."

Development of creative industries in Bandung is becoming a factor that strengthens the trade, hotels, and restaurants, as well as the services and manufacturing sector as the potential of the regions in Bandung [8].

Bandung statistics in 2013 showed that the number of overseas and domestic visitors increased drastically, roughly fifty percent on 2007. But in 2008, the number of visitors both foreign and domestic was decreased sharply due to a municipal waste problem. But it is growth again steadily from 2009 to 2012. This significant number triggered by creative industry in Bandung city as restaurants and factory outlet development.

Besides, the opening of a new toll road CIPULARANG (Cikampek-Purwakarta-Padalarang), linking Jakarta and Bandung since 2005 has made movements between the two locations easier and faster, as well as stimulating economic activities, especially weekend shopping and entertainment. Also, businesses such as hotels, restaurants, grocery shops and garment factories are taking advantage of the improved road infrastructure to locate in strategic areas. Indeed, Bandung has become a tourist city, with multiplier effects on the income of residents and social relationships transformation. However, the downside of the increased economic activities and high influx of people is that traffic congestion has become a common phenomenon, especially on weekends [9].

\section{Methodology}

This research applies a qualitative method using interview and observation. In-depth interviews were conducted with four (4) communities in Bandung City in two phases. The first phase was between February and March 2014. The second phase was conducted in November 2014. The interviews focused on ascertaining the level of collaboration between the local government and residents concerning tourism development. The questions covered the residents' interactions with the previous mayor who was in office between October 2003 and September 2013.

Respondents responded to over 20 questions and suggested measures to maximize benefits from tourism, while also taking steps to address its adverse effects. Each issue was followed by an open-ended question to probe for more information why they held such a point of view on a particular aspect. This method provided a broader picture about how they perceived their roles and allowed the researcher to investigate further other issues, which were not originally included in the questionnaire. The profiles of respondents are presented below:

\section{A. BCCF (Bandung Creative City Forum)}

$\mathrm{BCCF}$ is an association of a various group of communities, which was initiated in December 2008. The group comprises 45 registered representatives of the communities, but the actual number of members is huge. BCCF aims to nurture, develop the potential and creativity of local communities towards the development of Bandung City. For example, "Kampung Kreatif" (creative village) activities seeks to transform villages into tourist destinations by attracting visitors to village communities` events. Through this medium also, people are connected to local resources such as trash bank and processing of garbage into finished goods or souvenirs. Students also participate in this by creating and designing various products to meet market demands.

The overriding goal of the $\mathrm{BCCF}$ is to transform Bandung into one of the creative cities of the world by identifying, and analyzing the challenges of particular communities, with a view to seeking a local initiative to overcome such challenges. The organization believes that the cooperative dispositions of the people of Bandung can help to mobilize the needed social capital to actualize these dreams.

\section{B. Gemericik (Cikapundung Lovers Community)}

Following the Waste Processing's policy in 2008, Gemericik was established in 2010. Gemericik is a free community group, which is not bound by any institution. It is a college forum which is concerned with Cikapundung. It has about 30 registered members, although it is not all of them are active in its activities. The membership is drawn from faculty members of universities across Bandung City, with support from students. The association often receives support from Department of Environmental Management of Bandung City, regarding physical facilities, including building waste banks and waste management in general.

\section{Sakola Cikapundung (Cikapundung School)}

Sakola Cikapundung (Cikapundung School) is an association of students studying Anthropology at Padjadjaran University. The association, though not yet registered, comprises a group of approximately 100 volunteers who in partnership with residents and their colleagues from other campuses periodically conduct research around Cikapundung river and undertake other initiatives aimed at improving lives in Cikapundung. The association`s major activities are conducted in Dago Waterfall area.

Sakola Cikapundung activity is one of the community development initiatives undertaken by the Association to expand the carrying capacity of the river and promoting creativity in the transformation of local resources for commercial purposes. Given this, they organize periodic markets around Dago waterfalls, where such locally produced goods are displayed and sold. The Association is also engaged in teaching children across the community English language.

Organizations that are of the resolution of social problems in Bandung are scarce. Often, communities themselves mobilize to resolve their challenges, especially environment-related ones with little or no external assistance. Therefore, Sakola Cikapundung`s goal is to use Dago Waterfall area as a pilot project to champion environmentally friendly development, with the expectation that if the concept 
is successful, it would be replicated elsewhere. Dago Waterfall was the first tourist attraction destination of Bandung City. However, the high influx of tourists to the area coupled with poor maintenance practices led to the rapid deterioration of the waterfalls. Given the preceding, the association also aims to increase public awareness about the significance of the river, garner their support towards its sustainable use and transform the aesthetics quality of Dago waterfalls. Hence, the association is committed to revitalizing the environment, while also generating economic benefits from sustainable tourism.

\section{Komunitas Cikapundung (Cikapundung Community)}

Komunitas Cikapundung (Cikapundung Community) was founded in 2009 by a group of people who care for the environment primarily riverine environment. The majority of its members are residents of Cikapundung riverbank area, which cuts across six districts in Bandung city. The group is formally registered, with 52 registered pioneer members. However, the membership of the group has been fluctuating in recent times. The primary focus of the group is to re-orientate the anti-development attitudes of community members who often throw garbage into the Cikapundung river. The group believes that Cikapundung could better derive benefits from tourism if the locals imbibe more favorable attitudes and behavior towards preserving the natural and cultural properties of the community.

Komunitas Cikapundung (Cikapundung Community) has been empowered by the local government and Department of Tourism and Culture in Bandung City to develop initiatives that could transform Cikapundung river to a significant tourism destination

The respondent's opinion was transcribing and interpreted to obtain the main issues of the study. The study also utilized the triangulation method to acquire data. The process of triangulation is the application of different methods, such as the use of documents, maps, face to face interviews, observation, and writing of field notes and reflective memos. Supplementary interview was conducted to Department of Tourism and Culture, Department of Environmental Management and Department of Landscape of Bandung City in November 2014 to support the analysis of study result.

\section{RESULT}

\section{A. Communities' Perception of Social and Environmental Impacts of Bandung City Tourism}

The responses of residents and communities to tourism development and its impacts have received considerable attention in the last twenty years. King, Pizam, Milman (1993) asserted that most of these research focused on how various sections of the community differ in their reactions to tourism-induced impacts. The studies were mainly conducted in a single or a few neighboring communities. Unfortunately, it is often difficult to measure the social impacts of tourism. To a large extent, they are indirect. One may also suspect that there is another impact yet to be discovered. In general, hosts' attitudes and perceptions towards tourism vary on a continuous scale between negative to positive [10]. Unfortunately, it is often difficult to measure the known social impacts of tourism.
In the study of Greek island of Samos, it revealed that residents had high perceptions of the social impacts of Tourism, as expressed in the belief that it correlated with job creation, increased tax revenue, and increased personal income. However, they expressed fear that incidents of crime, drug trafficking, and abuse, as well as sexual harassment, will escalate as the development of the industry intensifies [11].

In the case of Bandung City, all respondents tended to perceive negative impacts from government's tourism program, including congestion and indiscriminate waste disposal. According to Sakola Cikapundung, waste is a big problem in this city because the government is only throwing the waste into the landfill, without recycling it or putting in place effective disposal measures. Hence, the volume of waste continues to increase.

Governments "Culinary Event" is also highlighted as the source of garbage problem. According to Cikapundung community, the culinary event, as government tourism program, has not been optimal for some reasons:

1) Many of the types of food offered are not West Java traditional food.

2) Waste from leftovers food and food package.

3) Entrepreneurs who are involved are mostly not Bandung residents.

Thus, waste accumulation has been the most obvious challenge of tourism development, coupled with throwing of garbage into rivers, which contaminate them and generate very offensive smells. Residents believe that If the "Culinary Event" were performed well and citizens were involved, the situation might have been better. However, they expressed dissatisfaction that up until now, there has been no invitation or cooperation from the government to manage the waste from this event.

The Cikapundung river problem earlier mentioned by Cikapundung Community Sssociation is not only the garbage issue, but also there has been a persistent challenge of water supply shortfall from the river. The causes attributed to this include:

1) Greening reduced on upstream.

2) Local water company of Bandung City (PDAM) is diverting the water meant for Bandung City residents.

3) Hydroelectric power plant using the river water to run the turbines.

On his part, Mr. Dian of Sakola Cikapundung believes that water supply shortages is due to the rapid infrastructural development in Bandung City, which has also triggered population expansion and increased demand for water. He added that when previously forested areas give way to buildings and other construction uses, it obviously adversely affects the watersheds of the community. Given the above, he criticized the policy of local autonomy thus: "because of this system; the government repeatedly gives permission to the private sector to construct buildings in order to increase tax revenue. City development by the private sector does not pay attention to the environment." (Field Interview with Sakola Cikapundung representative by the author on February 2014)

Sakola Cikapundung also believes that "planting trees" should be replaced with "growing trees," to discourage cutting down of trees, reasoning that it requires a longer period to grow trees, whereas 100 trees could be planted in just one day. 
Another issue raised by the respondents is congestion. Sakola Cikapundung opined that due to the relative security in Bandung City and the and hospitality of the residents, foreigners`demand for accommodations has soared, leading to the congestion of the city. However, because that Bandung City`s master plan developed by the Dutch government is not oriented towards accommodating huge population, the carriage capacity of the city has been overstretched as people continue to flock the city for tourism. Finally, buildings in Bandung City are increasingly being expanded, but their aesthetics attributes are often sacrificed in the process.

Similarly, Mr. Yadi of Cikapundung Community disclosed that the government is promoting and developing tourism to take advantage of the tax revenue to be generated from tourism-supportive factories, businesses, and hotels, but pay less attention to the adverse effects of tourism on local cultures and environment. Although the local government is trying to address the garbage challenge by providing litter boxes, it is also important to constantly enlighten residents and visitors about clean environment initiatives and mobilize their cooperation towards achieving this goal.

Furthermore, increased vehicular movements within the city have contributed a lot to air pollution, traffic congestion, in addition to other social impacts. For example, there has been an increased proliferation of vagabonds and beggars. Thus, BCCF notes:

"since the number of vehicles coming into Bandung, especially during the weekend continue to increase, causing traffic gridlock, they are taking advantage of this opportunity to beg from one vehicle to another, and eventually this become their livelihood." (Field Interview with BCCF representative by the author on February 2014).

In the same vein, Sakola Cikapundung and the local government observed that the rising numbers of the beggars might have been due to rise inequality occasioned by the tourism-induced rapid development in Bandung City, which has, in turn, escalated the number of people migrating to the city as beggars. Some respondents, including Mr. Dian, opined that the tourism industry has been more beneficial to foreign investors rather than the local people who mainly work for poor salaries. This is another area that is generating agitations among the residents. While tourism-induced luxurious hotels and other business ventures continually spring up in the city, many residents are still living in abject poverty. The quotation below appropriately captures the scenario:

"There is an awful sight when looking at the construction of new hotels near the slums of residents. This generates jealousy that could lead to social conflict" (Field Interview with Mr. Riki representative for Sakola Cikapundung, February 2014).

This reality has polarized the city between the residents who feel that they are left out of the benefits of tourism and foreign investors who live in affluence to the much glare of residents, a tendency that may culminate into inter-class conflicts. This fact mirrors the previous study that indeed local people were not receiving economic benefit from tourism development. Sadly, although the local government realizes that many of the residents live below the poverty line, initiatives to reverse this trend remain elusive.

\section{B. Community Inclusion for Tourism Development}

1) The Role of BCCF in Social Identity and Creativity

2) The BCCF's initiatives target the middle and lower class individuals in the community, so that they do not feel marginalized and apathetic towards tourism. Some of the key initiatives of the BCCF in this regard are presented below:

- 2008: Helarfest

Helarfest means "showing off". The locals show what they can do for development. These activities are planned by some deliberation community groups by developing seminars, planning concerts, exhibitions and so on that are performed under a single umbrella called "Helarfest." There are 31 events in Helarfest in August 2008.

- 2009: Helarfest

Since it has more and more participants, the events were increased as much as 67 events. Consequently, the period of Helarfest has now been extended to ten weeks.

- 2010: Semarak Bandung

Focused on public spaces and historic buildings. There were three (3) main activities:

1) Car Free Day: On Sunday morning, Dago area is closed from motor vehicles, so that playgrounds can be made for children, with snacks and so on, given, and the open library initiative.

2) Car free night: On Sunday evening, Braga area is closed from motor vehicles. Instead, meals and snacks stalls are prepared. In other words, on Sunday night, Braga area turns into a "Culinary Night" area. Street musicians often perform there.

3) Town Maker: BCCF effort to bring together designers, city government and the private sector to organize public facilities. For example: smoking room, bus stops, park benches and other public facilities. BCCF facilitate collaboration among the three parties and initiate discussion on important issues. The private sector, designer and local government. Private sector interest in advertising their product. In order to build public facilities, private sector requires permission from the government. Not only about the permission but also about tax relief, because the private sector is also doing something for the city. Unfortunately, this has not been realized because of tax issues. At least BCCF sought for public facilities in the "Town Maker" 2010.

- 2011: TUNZA

In collaboration with the United Nations Environment Program (UNEP) held "The International Children and Youth Conference", in which 1200 teenagers were invited with their chaperones from more than 60 countries. This event is used by BCCF to conduct a peaceful protest on the issue of Babakan Siliwangi forest that will be cut down to build new resort and hotel. Rejection of the community on this issue was not with shouting and demonstration in front of government office. A peaceful protest by embarking on a "forest walk" in Babakan Siliwangi. When opening the "Tunza" event, children planted trees in the "forest walk".

- 2011: Cycling

Other BCCF's role is to reduce congestion and pollution from motor vehicles. It is called "cycling" program that began in 2011. The program is "bike sharing" program or rents a bike. The aim of this program is that the visitors who come 
from Jakarta can use the rented bike for tourism activities in Bandung City. These efforts demonstrate the positive impact of "changing behavior" of some residents. "Changing behavior" mean changing the habits of people who are always on motorcycles become more environmentally friendly by cycling.

\section{- 2012: Helarfest}

Focus on four things, namely: rivers, forests, villages and city parks. Each resource is given to communities that can manage.

1) Forest activation: awarded to the organization called "Design Hub" held a concert for three days three nights for free in the woods Babakan Siliwangi. The show is called "Lightcestra." The goal is for people to understand that our city forests can be managed and utilized.

2) Parks: Awarded to the organization called "Eco Ekno" to make outbound for children over two days.

3) River: Awarded to the organization called "House de house" arranged a show to watch free movies (with inevitable screen), culinary night and performances. The goal is to unite the community to the river in a fun way.

4) Village: was done in "Taman Sari" village by initiating "kampung festival" (village festival) such as; kite painting for children, making stages and video mapping.

\section{- 2013: REGIA}

The urban forest activation. Picnic in the woods, yoga in the middle of the forest, children's workshops, open library and forest dining.

- 2014: Creative Village Festival

Festival that was held in Cicukang village involved the locals. The objective was to promote the village to be one of the tourism destination areas.

BCCF assert that their activities look like an acupuncture medicine. They call it " The City Acupuncture". When there are things that go wrong, they will react. For instance, to reduce the visitors who come by car, the organization encouraged the Cicukang village residents to make giant puppets that can only be seen from the train (to Bandung). All the activities of BCCF cover three areas: economic, social and environmental.

BCCF activities have brought positive impacts, especially the social dimension. Local communities want the greater recognition of BCCF's activities, because they provide an avenue through which these communities channel and express their interests, and thus offer a lesson to the government on how to embrace the local community.

\section{The Role of Sakola Cikapundung in Environment and Tourism}

The main focus of Sakola Cikapundung activities is to educate the residents. They teach them to improve their quality of life by improving their environmental condition. They also provide English language lessons to children. The extracts of the interview on their activities are presented in Table I.

Previously, local in this village was littering and mixing up their trashes. Then Sakola Cikapundung has taught people to sort them. Based on the author observation, now, the residents can process organic waste into compost and recycle non-organic waste. Sakola Cikapundung activities success in changing the resident's behavior in handling the waste for a better environmental condition.

\section{The Role of Cikapundung Community in Environment and Tourism}

Cikapundung community performs social service activities and cleaning up the river on Sundays. They opened Cikapundung River for tourism by offering some attractions such as rafting. Other initiative undertaken Cikapundung community are summarized in the Table II.

Based on author observation, the impact of the group's activities on residents surrounding the river is quite significant. Previously, residents blatantly threw garbage into the river and its surroundings, but now it has reduced. Before Cikapundung Community was established, the volume of waste in the river was very severe, but now the volume of waste has reduced.

Community cikapundung explained that before there was 10 tons/day of cow dung dumped into the river, but now decreasing to 2 tons / day. Cikapundung Community processes the rest of the cow dung to compost (fertilizer). It makes the riverbanks that had been filthy to become cleaner.

TABLE I: SAKOLA CIKAPUNDUNG ROLE FOR DEVELOPMENT

Year

Activities

Teaching English to the local community

Information

Shortage of residents who are proficient in English makes it difficult to communicate with tourists. Initially, they were teaching English to adults, but now they are also teaching children. This organization`s activities are carried out around Dago waterfall area. They also provide training for locals to make traditional crafts that are sold directly to tourist vising this area. This is the reason why English is needed for communication tool. They not only teach children English, but also other school subjects.

Children whose parents can not afford to provide additional tutoring outside of school are usually assisted with lessons to improve their performance in school.

The volunteers also teach the resident environmental education, including how to sort and process their waste. According to Sakola Cikapundung, government efforts to utilize Cikapundung River as a tourist attraction has not been optimum.

The government should be able to provide education to the community to change the behavior of "throwing Sorting and processing of $\begin{aligned} & \text { The government should be able to provide education to the com } \\ & \text { garbage into the river" into 3R (Reuse, Reduce, and Recycle) }\end{aligned}$ make garbage into consumable goods or crafts. These crafts serve as souvenirs which are offered to tourists. Apart from this, Sakola Cikapundung also provide training on household waste decomposer that processes household waste into fertilizer. The fertilizers are in turn used in their gardens. 
Cikapundung Community received an award from the Department of Public Works as the first winner of the arrangement of the area along the river on the occasion of the 2013 "World Water Day". However, Mr. Yadi noted that one of the most difficult challenges confronting the group is changing the mindset of people living in the riverbanks, in particular, who are renowned for having an uncivilized habit of throwing garbage into the river.

TABLEII: CIKAPUNDUNG COMMUNITY ROLE FOR DEVELOPMENT

\begin{tabular}{|c|c|} 
Activities/events \\
\hline 2009 \\
\hline 2011
\end{tabular}

(Source: Field Interview on February 2014 and November 2014)

TABLE III: GEMERICIK ROLE FOR DEVELOPMENT

\begin{tabular}{|c|c|}
\hline Year & Activities/ Events \\
\hline 2010 & Mapping the problems \\
\hline 2011 & $\begin{array}{l}\text { Held a cleanliness competition in several villages in } \\
\text { cooperation with Cikapundung Community }\end{array}$ \\
\hline 2012 & $\begin{array}{c}\text { Distributed questionnaires to community which its } \\
\text { output is to know what are the community desires } \\
\text { about how to manage garbage }\end{array}$ \\
\hline 2013-2014 & $\begin{array}{l}\text { Garbage bank system as a way to reduce waste in the } \\
\text { city }\end{array}$ \\
\hline
\end{tabular}

(Source: Field Interview on February 2014 and November 2014)

\section{E. The Role of Gemericik (Cikapundung Lover's Community) in Environment and Tourism}

Gemericik`s current goal is to promote community-based waste management. To achieve this, Gemericik provides training to residents on making crafts such as bags, wallets, dolls, etc. by utilizing the waste, mostly plastic waste. These unique works are sold as souvenir to tourists. This activity contributes significantly to Municipal Solid Waste management by reducing non-organic waste volume and combining local creativity to generate economic benefits. The other initiative of Gemericik (Cikapundung Lover's Community) are summarized in the Table III.

Gemericik also collaborates with the students through "pick up trash action" and "reprimand action" to reprimand people who carelessly throw garbage. However, this is only a volunteer activity which is only performed on the students campuses.

The biggest impact of Gemericik is in the area of increasing public awareness about the need for an effective garbage disposal system. Two methods are employed to achieve this goal, namely:

1) Garbage Bank:The customers are residents, who deposit valuable garbage in the Garbage Bank. The garbage is weighed and recorded in the passbook. The money is saved in the bank and usually withdrawn once a year.

2) The cooperative system: This aims to help small shops, which are given a business capital of between 100 and 200 thousand rupiahs in return for an equivalent value of garbage. The projects are being piloted in Taman Sari area, but currently, Gemericik is planning to establish an eco-district and eco-village. 
Gemericik processes waste products from garbage for sale as souvenirs. The waste is sold either directly to interested buyers or recycled to produce other items. Gemericik collaborates with BCCF to improve the design and packaging of finished goods made from waste to make them more attractive to consumers.

However, despite the commendable initiatives of the various community organizations, most of the respondents decried the lack of support from local government authorities They particularly expressed worry that even though they have made concerted efforts to promote tourism, both nationally and internationally, the response of the government has been less than encouraging. In the next section, the extent of their cooperation with the local government authorities is presented.

\section{F. Local Government and Communities' Cooperation to promote Tourism Development}

All the community organizations represented in this study revealed that they were not familiar with the previous and current administration`s programs on tourism development because it is not adequately publicized. Besides, Bandung City tourism development is unbalanced, especially in the field of Ecology. Bandung is better known for culinary tourism, which fits into the "creative economy" policy of the government, while other aspects of tourism remain less developed.

One respondent opined that a major weakness of the government's tourism development initiative in Bandung is that it lacks of schedules and adequate synchronization and promotions of local cultural performances, such as in Bali and other areas rich in cultural tourism. Examples include "Saung Angklung Udjo" and "Batik Kepret" which are credited to the initiatives and creativity of the local community rather than the local government's interventions.

Sakola Cikapundung disclosed that there has been no collaboration with the city government with respect to planning and implementing tourism-promotive interventions. The group added that on several occasions, they have attended meetings with the city government, with a view to improving the quality of the river. However, they expressed disappointment that the city government has not been forthcoming with meaningful action plans to achieve this. The organization added that the city government is instead shifting the responsibility to Cikapundung, which also passes through the districts of Bandung

Cikapundung Community believes that the previous mayor's policies regarding environmental, social, culture and art, were closely associated with tourism and were in line with Cikapundung`s desire to promote the use of riverbanks as public spaces. This is because such areas are suitable for observing the interface among social actors, their arts and the environment.

In other to promote tourism development policy, some government programs supported community activities, including:

1) Re-structuring the river in $2010-2012$ by improving activities in the riparian area.

2) Providing counseling to Riverbank residents to construct the door of the house opposite the river.
3) Building dams for storing water and protecting water quality.

However, the various groups in the community do not agree and cooperate with the government's entire program due to certain aspects of the government's decision that they find incompatible with the vision and mission of the community. For example, the government's decision concerning Babakan Siliwangi forest. The decision was about to cut down the forest and shift it into a resort area for tourism activities. However, Cikapundung community is trying to make this area into a forest area of the city as well as Babakan Siliwangi- a place where the family could play in the middle of nature and undertake other environmental activities.

Furthermore, Mr. Yadi of Cikapundung community asserts:

"we really need the government's assistance, especially in training, and monitoring of our activities. We are a hardworking people who will move into action so long as the government facilitates and provides better guidance for us for a better future. But, there is no such help from the government. The government can ask for cooperation from us, but we cannot ask for assistance from the government. The government never took our deliberations seriously." (Field Interview with Cikapundung Community representative by the author on November 2014).

Bandung City government tends to define "cooperation" as providing financial assistance, but on the contrary, the community and residents interests in seeking government`s cooperation is more in the area of policies that support their activities since this is beyond their capability. Sadly, this enabling policy remains a mirage.

Even though the local government often involves the communities in series of meetings aimed at discussing environment-related issues, they are usually not involved in developing programs to address such environmental issues. For example, Gemericik received assistance from the provincial rather than the city government to implement its waste management strategies. The local government seems not to care about the efforts that they are making. The government often attribute its poor support of community initiatives and proposals to promote tourism in Bandung city to the paucity of funds on its part.

Another reason is that the government feels that it is not necessary to promote tourism since visitors will always come anyways. However, this posture contradicts the government's program: "tourism promotion", that aims to increase the number of visitors. From the above contradiction, one could see that "tourism promotion" as used by the government is different from what the communities perceive and believe it to be. Thus, Gemericik better describes the situation:

"Although we are promoting the Cikapundung River to become a tourist attraction resource, the government does not reckon with the idea at all."

"Gemericik initiated eco-town park- garden that sells a variety of crafts made from trash, but this idea has not received support from the government,". (Field Interview with Gemericik representative by the author on November, 2014).

The program proposed by the community tourism is an environment-oriented tourism like the tourist village of 
BCCF, and water tourism in Cikapundung River, where souvenirs made from environmentally friendly procedures such as from trash (recycle goods) are presented and sold to visitors. Whereas "tourism promotion" as conceived by the local governments is a culinary tourism in shopping malls like Braga Festival.

One of the communities explained that the major attraction in Bandung City revolves around commerce, but all the respondents are worried about the adverse impacts of this and are stressing the need for the local government to put in place mitigating measures.

\section{G. Communities' Suggestions for Reducing the Negative Impacts of Tourism on Bandung City}

The impacts of tourism depend on the characteristics of tourists, including their length of stay, activity, mode of transport, etc. In order to mitigate these negative impacts, there is a need for supply side (government and local community) oriented preparation and planning through policies and programs that take into account not just the economic, but also the environmental, and social dimensions of tourism. However, in the absence of effective cooperation between the host communities and the local government, the prospects of achieving this goal may be threatened. Despite the challenges of fostering this collaboration, the host communities suggested some action plans aimed at reducing the negative impacts of tourism on Bandung City for consideration by the local government. These proposed measures are discussed in the next section.

\section{H. Greater commitment by the Local Government}

The host communities believe that the city government's efforts to reduce the negative impacts of tourism have not been successful. The BCCF describes this more appropriately thus:

"the effort of government to reduce congestion has not yielded desired results. Rather the government tourism promotion measures have escalated the number of visitors." (Field Interview with BCCF representative by the author on November 2014).

Furthermore, the government has yet to devise the effective system of managing tourism-induced waste, thereby posing environmental risks regarding polluted rivers and culverts due to an indiscriminate garbage disposal. A representative of Gemericik describes the situation thus:

"The provincial and municipal governments` efforts to address environmental issues has not been encouraging. It seems that they do not reckon with the complaints of the community representatives and the ignorance of the residents about the environmental and health threats posed by poor waste management initiatives further worsens the situation." (Field Interview with Gemericik representative by the author on November 2014).

Another challenge associated with tourism is urban congestion problem. The "creative economy" ideology upon which the city government' efforts to attract tourists is built have so far been concentrated in a few areas of the city. This leads to severe congestion in these areas of the city. Although the government has tried to tackle congestion by applying four in one at the Pasteur Highway every Saturday, to reduce incoming vehicle, it does not affect the congestion and density of Bandung City during weekends. This reality was further buttressed by a representative of BCCF thus:

"The government has a regular event for the promotion of tourism festivals such as the Braga Festival and Bandung Blossom which are held every year on the anniversary of the city, but does not provide adequate facilities in anticipation of any harmful effects. For example, by making provisions for smoking areas, parking lots and so on." (Field Interview with BCCF representative by the author on November 2014).

In summary, the argument of the host communities, is that the local government must strike a balance between its economic goal of generating increased revenue from tourism and the need to protect the environment and residents from the adverse effects (such as indiscriminate waste disposal, water and air pollution, congestion etc.).

\section{Develop Environment-friendly Tourism Attractions}

According to all respondents, tourism development initiatives in Bandung City are not environment-friendly. They focus only on the various culinary, without consideration of how they affect the environment. One example of such initiatives is the city park. Parks in Bandung have not been fully transformed to tourism assets. This view was expressed by a respondent of BCCF thus:

"In Bandung, there are 604 parks, but about 300 of these parks have been abandoned, with more likely to face the same fate. Even Babakan Siliwangi forest's management has been delegated to the private sector instead of being managed by the government." (Field Interview with BCCF representative by the author on February 2014).

Communities believe that if Bandung City becomes famous for its culinary, putting in place an efficient and effective waste management system should be a major focus on the government because it is one of the factors that visitors consider in deciding their destinations. In Bandung City, there are some tourism resources, which meet the need of environment-friendly tourism, but the local government seems to be more interested in generating income.

Gemericik thus suggested that the local government should designate environment-oriented tourism destinations that serve as real markets. Furthermore, Gemericik believes that "Integrating the concept of traveling with the environment is a commercial package," which made Gemericik initiate the concept of an "eco-town Park," and the Cikapundung water attractions" but the government's response has been less than encouraging.

\section{J. Public Awareness Initiatives}

According to Cikapundung Community, raising public awareness on the need to protect the environment has been the most difficult challenge of tourism development. Poverty and low level of education in the community are significant development concern in the city. For example, although the government has made efforts to rid the streets of garbage by trash cans in strategic public locations, people still do not throw trash into these trash cans. According to Mr. Riki of Sakola Cikapundung:

"The local government puts the trash cans, divided into one for organic and another for non-organic waste in public spaces, but only a few have survived. Resident destroys or took the trash cans because the city government does not carry out adequate enlightenment campaigns to educate citizens about the importance of waste sorting is. Therefore, 
residents are still not familiar with waste segregation." (Field Interview with Sakola Cikapundung representative by the author on February 2014).

People still take delight in polluting and destroying green spaces, rather than maintaining them. For example, "Cikapundung is the largest river in Bandung and splits Bandung into two. Water is the source of life, but residents often throw garbage into the river." This behavior sums up the attitude of the residents towards the preservation of environmental resources. Given the preceding, they argue that the government needs to review and create programs to educate the public, especially about the opportunities and challenges inherent in tourism. Such initiatives should be predicated on a bottom-up approach as buttressed by one respondent below:

"It should advocate a bottom-up approach. By bottom-up approach, the government is required to hear what is desired by the residents, and it becomes before developing the program." (Field Interview with Sakola Cikapundung representative by the author on November 2014).

This is particularly important because the concept of tourism thrives on making citizens good stewards to every guest who comes. Periodic Training through workshops and seminars are required to keep stakeholders abreast of issues relating to tourism constantly. For instance, BCCF representative stressed that:

"The public transport and taxi drivers need to be regularly trained on how to relate with people from diverse socio-cultural backgrounds as the first point of contact for most tourists." (Field Interview with BCCF representative by the author on November 2014).

In conclusion, the local government's interventions should be based on making the host residents perform more than the roles of spectators. Rather they should be made to take the active part in all stages of planning, developing, monitoring and evaluating the implementation of tourism development policy. This is a sure way to build trust that can ensure that all stakeholders in the tourism industry generate continuous mutual benefits from tourism.

\section{DISCUSSION AND CONCLUSION}

This paper investigates the community's activities in reducing adverse impacts from tourism development. The perceived effects reported by informants coincided with the majority of those identified in previous studies. Communities recognized that tourism development in Bandung City is promoted only for generating economy benefit through an idea so-called "creative economy." This concept was successful in increasing city revenue along with an increasing number of tourist. Whereas, the negative impacts gained from this rapid growth tourism development especial environmental and social consequences that affected to resident's quality of life has less attention by the local government.

Tourism development increases the amounts of waste generated in a various touristic destination, threatening the local environment due to improper waste management facilities. This study revealed waste problem is one of the significant issues of tourism development impacts in Bandung city. The landslide incident of Leuwigajah landfill in 2005 forced all stakeholders to recognize the importance of
Municipal Solid Waste (MSW) management's improvement. The concept of reduces, reuse, recycles (3R) is considered as the key for problem-solving of MSW [12].

According to Waste Management Agency (PD. Kebersihan), Bandung City generated waste over than 1500 tons/day. The waste amount that disposed to final disposal is more than 1100 tons/day. About 200 tons processed through 3R activities. In 2012, $16 \%$ of MSW was managed through 3R. Waste reduction implemented by community, informal sectors and Waste Management Agency by 9\%.7\% of MSW was handling through recycling and composting by communities and informal sector. Communities role in educating residents resulted in the changes of behavior from improper waste handling to $3 \mathrm{R}$ waste management and waste reduction in landfill (see Fig. 1).

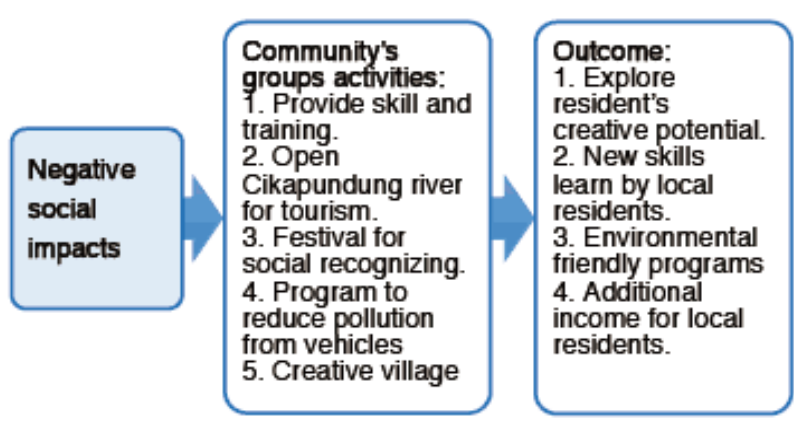

Fig. 1. Role of communities on 3R waste management.

The rapid growth of tourism in Bandung City also causes a socio-economic impact. Bandung Creative City Forum (BCCF) was talking about social inequality that occurred in the urban community. The same statement also described by Sakola Cikapundung that the social gap is getting higher. Bandung City residents have become apathetic in the middle of the rapid development in the city. Most of them don't have provision skill that can be useful as a livelihood (see Figure 2).

This social issue has motivated all respondents (community groups) to make efforts that could mitigate the adverse impacts. BCCF, Komunitas Cikapundung, Sakola Cikapundung, dan Gemericik are giving an example of government on how to embrace and develop residents through social activities and provide them skill and training.

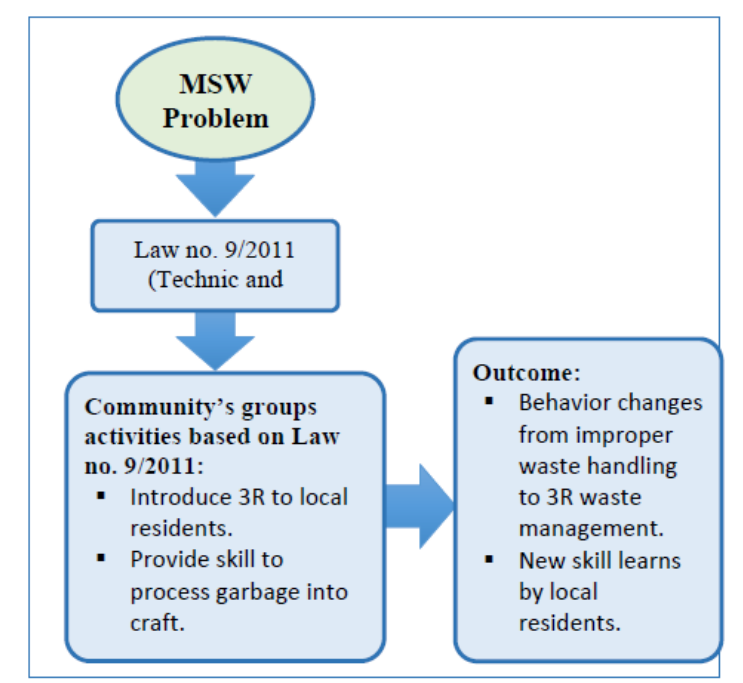

Fig. 2. Communities' role on social identity and tourism development. 
Cikapundung Community is doing social service activities and clean-up the river on Sunday. They opened Cikapundung River for tourism by offering some attraction such as rafting. Sakola Cikapundung introduces 3R waste management to the residents, teaching English to children, and they also provide instruction to housewives to make garbage into goods used or craft. This craft is expected to be souvenirs offered to the tourists. Besides, Sakola Cikapundung also provides training for a household waste composer that process of household waste into fertilizer. The fertilizers can be used in their gardens. Other significant activities are "Helarfest", Car Free days and Creative village festival which held by BCCF. Car Free days is a program to reduce pollution from vehicles. Another is Creative Village, which aiming to build resident of potential to attract tourists so that residents can feel the direct economic impact of tourism activities.

Local communities are trying to make environmentally friendly tourism resources and facilities that also marketable. Unfortunately, these efforts have less support by the government for some reasons. Even so, they keep doing their action and hoping that it can help to reduce adverse impacts caused by unbalancing tourism development.

\section{REFERENCES}

[1] M. Muganda, A. Sirima, and P. Ezra Marwa, "The role of local communities in tourism development: Grassroots perspectives from tanzania," vol. 41, no. 1, pp. 53-66, 2013.

[2] J. Williams and R. Lawson, "Community issues and resident opinions of tourism," Annals of Tourism Research, vol. 28, no. 2, pp. 269-290, 2001.

[3] G. S. David, "Community participation in tourism planning," Tourism Management, vol. 15, no. 2, pp. 98-108, 1994.

[4] D. Getz, The Impact of Tourism in Badenoch and Strathspey, Edinburgh: Highlands and Islands Development Board, 1982.
[5] D. Matarrita-Cascante, M. A. Brennan, and A. E. Luloff, "Community agency and sustainable tourism development: The case of La Fortuna, Costa Rica," Journal of Sustainable Tourism, vol. 18, pp. 735-756, 2010.

[6] K. Pongponrat, "Participatory management process in local tourism development: A case study on fisherman village on Samui Island, Thailand," Asia Pacific Journal of Tourism Research, 2011.

[7] Bandung in Number, Bandung Statistic Bureau, 2015.

[8] Performance and Accountability Report (LAKIP) of Bandung City, 2012.

[9] T. Firman, "The continuity and change in mega-urbanization in Indonesia: A survey of Jakarta-Bandung region (JBR) development," Elsevier Ltd, 2008.

[10] B. King, A. Pizam, and A. Milman, "Social impacts of tourism: Host perceptions," Annals of Tourism Research, vol. 20, pp. 650-665, 1993.

[11] N. Haralambopolous and A. Pizam, "Perceived impacts of tourism: The case of samos," Annals of Tourism Research, vol. 23, pp. 503-526, 1996.

[12] E. Damanhuri, I. M. Wahyu, R. Ramang, and T. Padmi, "Evaluation of municipal solid waste flow in the Bandung metropolisan area, Indonesia," The $3^{\text {rd }}$ Expert Meeting in solid Waste Management in Asia and Pacific Islands, Cycles Waste Management, Springer, 2009.

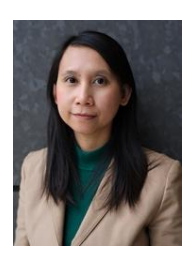

Yulia Windarti was born in Indonesia. Yulia received her degree in Japanese language and literature at Padjadjaran University, Bandung, Indonesia in 2004. From April 2003 until March 2004, she was studying Japanese at Rikkyo University, Tokyo, as a special international student. She then changed directions to pursue a master degree in Management and completed her degree, MBA at Hamamatsu University, Japan, from 2009 to 2011. Her research was focusing in management of hotel and hospitality in Japan. Current, she is doing her research for Ph.D program of social and culture study at Graduate School of International Development (GSID) of Nagoya University, Japan. Her current research is focusing on tourism development and policy in Indonesia. During her study in doctorate program, she was working as research assistant for "Leading graduate school, Ph.D. Professional" at Nagoya University. 